\section{The role of professional networks in radiology services}

\section{Gray Southon ${ }^{1}$}

Suggested citation: Southon G. The role of professional networks in radiology services. Rev Panam Salud Publica. 2006; 20(2/3):99-103.

Key words: health services, health personnel, community networks, group processes, organizational culture, professional autonomy, radiology.

University of Auckland, School of Population Health, Auckland, New Zealand. Send correspondence to: Gray Southon, 56 Robins Rd, Tauranga, New Zealand; telephone: 647 5787119; cell phone: 64211 020 977; e-mail: gray@southon.net
SYNOPSIS

Recent developments in public health policy have highlighted the central role of the clinical work force in the success of policy implementation, and thus the need for effective human resource policies. Given the high level of professionalism in health services, a number of special issues arise, including the organizational structures that best support professional work. Experiences from global industries that rely on a highly expert work force show that hierarchical control structures need to be supplemented by a variety of networks. Networks are complex structures that are very different from normal hierarchies, and they need to be effectively understood. While they usually develop spontaneously, they are often not optimally structured, adequately supported, or effectively exploited by health service organizations. It is important to understand the nature of networks and how they can be promoted in order to ensure that clinicians are appropriately supported in providing and enhancing services.

In health policy, the role of clinicians is commonly considered to be that of functionaries performing defined tasks as the need arises, while the principal task of management is to ensure that the staff hired is competent and that the required tasks are performed. However, some authors (1-3) have recently highlighted the fallacies of such an approach and have emphasized the need for effective human resource policies to engage with the social and political dynamics of clinical professionals. The role of the professional goes beyond merely providing services to actually defining the nature of the service required for individual patients, and it may extend to enhancing service capabilities. This paper focuses on the subject of human resource policy in the field of radiology.

The provision of radiological services depends on the capability of a number of types of professionals, particularly diagnostic and therapeutic radiologists and radiographers, as well as related staff such as medical physicists. The competence of these professionals depends not only on their initial training, but also on their desire and ability to monitor their performance, to upgrade their skills, and to adapt to local needs. Further, the effectiveness of professionals depends on their ability to integrate their services with a range of other local professional and community activities in order to accommodate the specific needs of each patient. This is the only means of ensuring that quality continuity of care can be achieved in radiology, especially in therapeutic radiology. 
Such dependence on the skills and initiative of operational staff is common to many industries, and there are valuable lessons that can be drawn, particularly from large global corporations. We use these lessons to develop an understanding of the types of structures that would best enable clinical professionals to effectively contribute to the provision and reform of health services.

\section{THE CENTRAL ROLE OF CLINICAL CAPABLITY}

Clinical capability is basic to both the definition and delivery of health services. It is only through the skills, values, and commitment of professional clinicians that the appropriate service for each patient can be identified and delivered. It is clinicians who assess the nature of a patient's need, what diagnostic methods to employ, what treatments to consider, how to bring the resources of the system to bear on that need, how to work with other clinicians and services, and how to best engage the patient in light of his or her particular cultural environment (4). Such decision-making may require clinicians to balance the potentially competing interests of the patient, the system, the society, their profession, and their own personal needs. These skills depend not only on the science and "state of the art" of clinical practice but also on the local context and the way that the health service integrates with local communities. Further, by using their considerable intelligence and intimate knowledge of the task and the system, clinicians may also play a major role in enhancing the nature of the service and directing its future development.

Such realities are becoming recognized in the economic theory of social capital. Francis Fukuyama (5) notes: "The fact of the matter is that coordination based on informal norms remains an important part of modern economies, and arguably becomes more important as the nature of economic activity becomes more complex and technologically sophisticated. Many complex services are very costly to monitor and are better controlled through internalized professional standards than through formal monitoring mechanisms."

There are many ways in which effective decision-making at the clinical level is central to quality health services, and it is only through supporting such decision-making that services can be optimized.

\section{THE ROLE OF NETWORKS}

The most important organizational structure for supporting this clinical competence is the net- work. Networks are complexes of links among many different parties, driven largely by the interests of those parties and facilitated by trust (6). These parties may be individual clinicians, academics, departments, service providers, or other entities. Networks have always played important roles in the development and use of knowledge, in such forms as guilds, professions, associations, and, more recently, the complex of discussion groups that have developed on the Internet. Networks are central to the support and enhancement of professionalism.

There is an increasing recognition in the commercial sector of the role of networks, particularly in highly skilled professional service industries (7). Many global corporations, such as British Petroleum, Ernst \& Young, Hewlett-Packard, and Xerox, have been paying much greater attention to the way that they use knowledge (8), and they are promoting networks of various types, sometimes called "communities of practice," as a means of enhancing organizational skills and capabilities (9). The IBM Center for The Business of Government has identified networks, in the form of communities of practice, to be a new tool for government managers that is capable of driving nationwide changes in government services, using the energy and commitment of operational staff (10). In the United Nations the Cardoso Report takes networks as the core structure for enabling the engagement of civil society in the UN system (11).

Networks are common in health services, and they are fundamental to service provision. Often arising naturally, networks are frequently informal and often quite ephemeral and difficult to define. They provide the potential for a flexible engagement of the enormous reservoir of interest and expertise that resides at many levels throughout the health system, coordinating diverse interests and responding to challenges as they arise. For instance, the spontaneous networks of specialists who responded to the recent SARS epidemic have been officially recognized by the World Health Organization (3). Much of the work in clinical research in diagnosis and therapy is through networks of institutions and practitioners.

Networks can take many different forms, being either formal (clearly defined and structured) or informal (often diffuse and amorphous). Networks can have a variety of functions, with some of the more important being expertise networks, referral networks, and program networks.

Expertise networks involve the sharing and development of specialized knowledge amongst groups of similarly qualified people such as radiologists and radiographers. These are often incorporated into formal structures such as colleges and societies (e.g., the International Society of Radiology 
and the International Society of Radiographers and Radiological Technologists). There may also be informal associations for more specialized areas with, for example, networks of interventional radiologists, chief radiographers, breast cancer radiation oncologists, or medical physicists. Such networks play critical roles in maintaining and developing the expertise required for service provision, and they provide a sense of identity and assurance against the uncertainties of expert practice, particularly for those clinicians who are otherwise isolated (12). These uncertainties may arise from many sources, ranging from the nature of the patient, the disease, and the appropriate treatment to the political, organizational, legal, and financial environment in which clinicians work. Patients may form cancer support groups that not only become networks of people sharing their experience of the disease and treatment but also constitute a very important source of knowledge.

Referral networks enable a range of expertises to be accessed to address individual cases. For instance, a general practitioner may refer a patient to a medical oncologist, who refers him to a radiation oncologist, who treats and then refers the patient back to the medical oncologist, who then refers him to a physiotherapist to address the effects of the treatment. These networks form key coordinating mechanisms for practitioners, usually developed informally over a period of time as clinicians learn whom they can work with and trust. Radiology and oncology services often receive many of their patients through such networks, and those services may use similar networks to engage other services to address individual patient needs.

Program networks are more structured networks, commonly used in oncology services, that coordinate the different expertises required to provide for particular types of patients. Such networks may combine tertiary diagnostic and therapeutic services with primary care, community services, and mutual support groups of patients. Because of the many different specialty services involved in dealing with cancer, it is only natural that institutions work together in networks. Such networks enable the sophisticated services to be available in major centers, which work in conjunction with locally-provided lower-level services. The National Health Service of the United Kingdom has used such networks as a central component in the revitalization of cancer services (13). In diagnostic radiology, such networks enable the cooperation required for teleradiological services to operate effectively (14).

The value of networks lies in their ability to handle complex, experiential, and specialist knowledge in a way that is responsive to changing and unpredictable circumstances. Networks make possible the comparison of experiences and practices by those who know them in detail. Networks also facilitate the sharing of opinions about how to deal with a particular case, a new drug or technology, or problems with current practices. Networks can draw on expertise relevant to particular issues and local situations. Networks can be a means of distilling, consolidating, enhancing, and validating knowledge that is distributed among a wide range of people. Networks can engage people directly involved in clinical services in both assuring performance and enhancing it (12).

Networking can also enable specialist services and departments to work together cooperatively, allowing them to learn from each other in identifying inefficiencies, developing innovations, testing alternative systems, and benchmarking performance (15). Thus, the strengths of the stronger radiotherapy centers can be used to assist other centers to enhance the quality of their services.

Despite the vital role that networks play in most organizations, they are seldom effectively recognized. Organizational structure is usually presented as a hierarchy, and networks remain largely invisible. For instance, Savage (16) analyzes the way that hierarchical control has been considered the ideal for health services in the United States, but in a way that ignores the role of networks. In a major analysis of health sector worker motivation, Franco et al. (17) consider only the "alignment [of clinical attitudes] with the goals of the organization," completely ignoring the potential of wider influence of professional standards and community goals that come through networks.

This lack of attention to networks results in demands being placed on hierarchies that they often cannot fulfill. The typical hospital management, for instance, is incapable of mastering all the specialty disciplines for which they are responsible. Further, hierarchies have great difficulty in handling the multitude of problems that require indepth practical knowledge, consistency across the system, and widespread commitment of the people involved. In health, such problems cover a wide range of quite critical issues, such as service coordination, manpower training, clinical standards, community education, and technology deployment.

On the other hand, networks can keep clinicians in touch with each other over broad regions, enabling them to learn from the best experiences of others, avoid the worst outcomes, and minimize the discrepancies in practices that inevitably develop. In this way, professional integrity and consistency can be maintained so as to enable coherent training programs and practice standards, professional mobility, and career viability. For example, these kinds of enhancements of service standards are being achieved in the Australian state of New South 
Wales by the networking of a number of specialist services, including radiology (18).

Managing networks presents quite a challenge, given that they are driven by very different principles than is the standard hierarchy (12). Networks are focused on expert achievement of tasks held in common, and they are driven by the members themselves. Authority is determined by the most competent colleagues, wherever they may be, and there is a resistance to external interference, especially if it is seen to be antagonistic. Networks are based on collegial values, intrinsic motivation, and trust.

In reality, it is necessary to deal with the interplay between the two organizational structures of management hierarchy and clinical networks as they coexist. Each structure brings very different principles, strengths, and weaknesses, but at the same time they all complement each other in providing effective services. Hierarchies bring order, control, and accountability, while networks bring knowledge, innovation, and capability. Managers, politicians, policymakers, and the public are often more comfortable with hierarchies, while professionals tend to be more comfortable with networks.

How, then, can managers ensure that networks are contributing optimally to the organization? The first step is to recognize that networks do not respond to direct control, and it is necessary to work with them, rather than to manage them in the traditional sense. However, even identifying what the actual structure and function of existing networks are may not be easy. Networks may be quite diffuse in structure and indeterminate in function, and members may feel that such networks are their own private concern. Clinicians may not be fully aware of the networks that they engage in, or they may be embarrassed because of their lack of networking, preferring to work in professional isolation. However, whatever understanding of networks that managers and policymakers may glean would be useful in establishing which aspects of networks can best be encouraged in their particular situation.

It is also important to consider the nature of the networks and how they impact on clinical work. If, for instance, expertise networks are led by distant centers of excellence, then clinicians are likely to be very aware of the latest technology and scientific developments, but clinicians may have difficulty relating those developments to the specific demands of the local community. If, alternatively, networking is largely with other centers within the same region, then there will be a much greater awareness of and ability to cope with the issues common to that region. Such networks may in fact be the source of considerable initiative in addressing such issues. Also, if local networks are strong, then the chances of effective referral and program coordination are considerably enhanced.

Networks can be encouraged by promoting regional specialty conferences and local multidisciplinary meetings. They can also be facilitated by establishing a communications infrastructure, as is the case with the Health Partnership for Knowledge Sharing and Learning in the Americas, which is an initiative of the Pan American Health Organization and the World Bank (19). On the local level, more generous vacation allowances could be provided for clinicians if they combined their vacations with visits to other regional centers. Networks could be stimulated by asking clinicians to use them to develop responses to critical issues in which they have an interest, such as cancer prevention or diagnostic screening programs. Such requests, however, may require the assurance that managers will be receptive to well-justified requests and will support them financially. Networks of clinicians can also engage with representatives of community groups and with policymakers to develop greater trust and understanding with these groups. In general, clinicians, and for that matter managers, should be expected to be aware of equivalent practices in other institutions and should be continually learning from them.

While networks have major functional benefits, they also have significant implications for the way management works and power is distributed. For instance, clinicians are unlikely to undertake constructive initiatives unless they feel confident in the willingness and capability of management to also respond constructively and support their activities. Further, networks may become power centers in themselves, and they may exert a significant influence on management. The challenge for public health policymakers is to engage with the networks constructively as key forces for health services development.

\section{CONCLUSION}

For radiology and other specialist services to be best promoted, it is important that managers and policymakers engage with the intellectual capabilities of clinicians and develop the organizational structures that best enable clinicians to contribute to enhancing the services provided. In order to achieve this, it is important to understand the role of networks and to promote them in ways that will enhance the ability of the services to address local needs. 


\section{SINOPSIS}

\section{El papel de las redes de profesionales en los servicios de radiología}

Algunos acontecimientos recientes en el ámbito de las politicas sanitarias han puesto de relieve el papel fundamental que desempeña el personal clínico en la ejecución de dichas políticas. Es importante, por lo tanto, que las politicas de recursos humanos sean eficaces. En los servicios de salud el personal suele ser de nivel profesional en su mayor parte $y$, como resultado, hay varias cuestiones que es preciso examinar, entre ellas qué estructuras organizacionales conducen a un mejor desempeño profesional. Según la experiencia acumulada por industrias multinacionales con una fuerza de trabajo muy experta, las estructuras basadas en un control jerárquico tienen que suplementarse con una serie de redes de profesionales. Es preciso entender a cabalidad estas últimas, que son estructuras complejas y muy distintas de las jerarquías ordinarias. Aunque por lo general estas redes se forman espontáneamente, a menudo ni tienen una estructura óptima ni cuentan con un apoyo adecuado, a lo cual se suma que las organizaciones sanitarias raras veces saben aprovecharlas. Es importante conocer la naturaleza de las redes y saber fomentarlas a fin de conseguir que el personal clínico profesional reciba el apoyo necesario para prestar bien sus servicios y poder mejorarlos.

Palabras clave: servicios de salud, personal de salud, redes comunitarias, procesos de grupo, cultura organizacional, autonomía profesional, radiología.

\section{REFERENCES}

1. Rigoli F, Dussault G. The interface between health sector reform and human resources in health. Human Resour Health. 2003;1:9.

2. Biscoe G. Human resources: the political and policy context. Geneva: World Health Organization; 2001.

3. World Health Organization. World health report 2003: shaping the future. Geneva: WHO; 2003.

4. Cox K. Doctor and patient: exploring clinical thinking. Sydney: UNSW Press; 1999.

5. Fukuyama F. Social capital and civil society. Available from: http://www.imf. org/external/pubs/ft/seminar/1999/ reforms/fukuyama.htm [Internet site]. Accessed 16 May 2005.

6. Levin DZ, Cross R, Abrams LC, Lesser EL. Trust and knowledge sharing: a critical combination. Available from: http :// www-1.ibm.com/services/us/index. wss/ibvstudy/imc/a1002447? cntxt= a1000452 [Internet site]. Accessed 17 May 2005.

7. Dawson R. Living networks: leading your company, customers, and partners in the hyper-connected economy. New York: Prentice Hall; 2003.

8. Seely Brown J, Duguid P. The social life of information. Boston: Harvard Business School Press; 2000.
9. Wenger E. Communities of practice: learning, meaning, and identity. Cambridge: Cambridge University Press; 1998.

10. Snyder WM, de Souza Briggs X. Communities of practice: a new tool for government managers. Available from: http:/ / www.businessofgovernment. org/pdfs/Snyder_report.pdf [Internet site]. Accessed 16 May 2005.

11. United Nations. We the peoples: civil society, the United Nations and global governance. Available from: http:// www.un.org/dpi/ngosection/ N0437641.pdf [Internet site]. Accessed 16 May 2005. (Report A/58/ 817).

12. Fenton E, Harvey J, Griffiths F, Wild A, Sturt J. Reflections from organizational science on the development of primary health care research networks. Fam Pract. 2001;18(5):540-4.

13. Kerr D, Bevan H, Gowland B, Penny J, Berwick D. Redesigning cancer care. BMJ. 2002;324(7330):164-6.

14. Aas IH. Organizational cooperation in teleradiology. J Telemed Telecare. 2005; 11(1):45-50.

15. Southon G. Advancing knowledge in health: a knowledge-based health system. Available from: http://home pages. paradise.net.nz/southon/Gray/advknow. rtf [Internet site]. Accessed 4 September 2004.

16. Savage DA. Professional sovereignty revisited: the network transformation of American medicine. J Health Politics Policy Law. 2004;29(4-5):661-77.

17. Franco LM, Bennett $S$, Kanfer R. Health sector reform and public sector health worker motivation: a conceptual framework. Soc Sci Med. 2002;54(8):1255-66.

18. Braithwaite J, Goulston K. Turning the health system $90^{\circ}$ down under. Lancet. 2004;364:397-9.

19. Pan American Health Organization. The World Bank and the Pan American Health Organization inaugurate health partnership for knowledge sharing and learning in the Americas [press release]. Available from: http://www.paho.org/ English/DD/PIN/pr031015.htm [Internet site]. Accessed 26 June 2004.

Manuscript received on 14 December 2004. Revised version accepted for publication on 26 May 2005. 